\begin{tabular}{l|c|c}
\hline ISSN: 0001-5113 & ACTA ADRIAT., & ORIGINAL SCIENTIFIC PAPER \\
AADRAY & $58(1): 147-156,2017$ & \\
\hline
\end{tabular}

\title{
Recent records of swordfish attacks on harpoon vessels in the Sicilian waters (Mediterranean Sea)
}

\author{
Teresa ROMEO ${ }^{1}$, Giovanni AMMENDOLIA ${ }^{1}$, Simonepietro CANESE², \\ Franco ANDALORO ${ }^{3}$ and Pietro BATTAGLIA ${ }^{1}$ \\ ${ }^{1}$ ISPRA (Institute for Environmental Protection and Research) - Laboratory of Ichthyology and \\ Marine Ecology, Via dei Mille 46 - 98057 Milazzo (ME), Italy \\ ${ }^{2}$ ISPRA (Institute for Environmental Protection and Research) - Via Vitaliano Brancati 60 - \\ 00166 Roma, Italy
}

${ }^{3}$ ISPRA (Institute for Environmental Protection and Research) - STS of Palermo, c/o Residence Marbela, via Palermo, Salvatore Puglisi 9, 90143 Palermo, Italy

Corresponding author, e-mail: teresa.romeo@isprambiente.it

Recent cases of swordfish attacks on harpoon fishing vessels of the Sicilian fleet were examined and the particular behavior adopted by this fish during the approach to fishermen was described.

The information was collected in the period between 1999 and 2014 in Sicilian waters (Mediterranean Sea) through interviews with harpoon fishermen and through direct observations during research activities. Additional cases of the attacks from the previous years are also reported. Overall, 29 cases of swordfish aggressive behavior against fishing boats were documented. Swordfish usually attacked when provoked or when wanted to defend its mate and in several cases, it tried to pierce the boat by the bill. Some attacks culminated with a damage to the target, whereas no injuries to humans were recorded.

Key words: Xiphias gladius, behavior, attack, human risk, harpoon fishery, Mediterranean Sea

\section{INTRODUCTION}

The swordfish, Xiphias gladius (Linnaeus, 1758 ) is the only species belonging to the Xiphiidae family that inhabits tropical and temperate seas of the world. It is an apex opportunistic predator and a fast swimmer (CANESE et al., 2008; LEE et al., 2009). It can perform rapid depth excursions from $400-500 \mathrm{~m}$ to the surface in few minutes (CAREY, 1981; CANESE et al., 2004, 2008). The greatest swimming depth $(900 \mathrm{~m})$ was reported by TAKAHASHI et al. (2003) in the Pacific Ocean.

The name originates from the Latin word "gladius" which means "sword" and describes a peculiar characteristic of the species: a long rostrum similar to a sword. A prominent bone protruding from the snout is also common to other billfishes as spearfish, sailfish and marlins and it has several functions, such as defense (FIERSTINE, 1997; FIERSTINE et al., 1997), improve- 
ment of swimming hydrodynamics (WISNER, 1958; OVCHINNIKOV, 1970; SAGONG et al., 2013) and feeding strategy (SCOTT \& TIBBO, 1968; STILLWELL \& KOHLER, 1985; FRAZIER et al., 1994; SHIMOSE et al., 2007; DOMENICI et al., 2014). However, rostrum of the swordfish is much longer and wider than the rostrum of other billfish. Studies on swordfish feeding behavior described the usefulness of the elongated rostrum for killing and cutting prey using a lateral splashing (SCOTT $\&$ TIBBO 1968). This was proven by the fragments of the prey found in the stomach contents with evident injuries caused by the bill, especially on squids and silver scabbardfish that were split into two or more sections (STILLWELL \& $\mathrm{KOH}-$ LER 1985; ROMEO et al., 2009a). A well-developed visual system and a muscle tissue that warms the blood flowing to the brain and eyes, especially when the fish is in the cold waters, allow swordfish to individuate its prey also from long distances, increasing the success of predation. Moreover, FRITCHES et al. (2005) proposed a possibility that swordfish might see in color. All these characteristics and abilities make the swordfish a capable predator.

Nevertheless, the function of the bill is well recognized in feeding strategy and in swordfish attacks on the objects (ships, boats, fishing vessels), but also attacks on large pelagic animals (whales, sharks and turtles) were reported (GOODE, 1882; GUDGER, 1938, 1940; ELLIS, 2013). Attacks on small submersibles or mesoscaphes are also known. A careful description of an attack occurred during an expedition by the Submarine Alvin in Florida was given (ZARUDSK \& HAEDRICH, 1974); in this case, a swordfish impaled (without releasing) itself in a joint of the submersible's upper and lower parts and it was caught when the submersible surfaced. ELLIS (2013) described other similar cases.

Cases of swordfish attacks to humans have been reported from the ocean waters and the events have been often examined from a clinic point of view. For instance, some specific swordfish attacks to fishermen were described: Brazil (HADDAD et al., 2009); Spain (GALBIS et al., 2002; MENDONÇA-CARIDAD et al., 2008). Studies reported that this fish behaves dangerously when provoked or disturbed. In Malaysia, a man was injured while swimming and the attack culminated with his death (GOOI et al., 2006); in Santorini Island (Greece) another case of probably unprovoked swordfish attack to a woman who was swimming was clinically analyzed (GEORGIADOU et al., 2010).

In the Mediterranean Sea, the swordfish behavior has been studied by a direct visual approach onboard harpoon fishing vessels that operate in the Strait of Messina and the nearby areas (ROMEO et al., 2009a, 2010, 2011b, 2015). Indeed, this fishing activity represents a useful opportunity to study the surface swimming behavior of this fish during its reproductive season, since it is carried out during daylight and based on a visual exploration of the sea surface and sighting of specimens. Studies performed by pop-up archival tags in the Strait of Messina demonstrated that swordfish usually stays in surface layers during night hours, whereas, during daylight, it carries out depth excursions from deep waters to the sea surface, remaining there for about 1 hour (CANESE et al., 2004, 2008). For this reason, the resource becomes available to the harpoon fishing in the area (ROMEO et al., 2015).

Based on this information, the aim of this paper is to report recent records of swordfish attacks to harpoon fishing vessels of the Sicilian fleet and examine the particular behavior adopted by this fish while approaching fishermen and evaluate if this aggressive behavior represents any risk for humans in the study area.

\section{MATERIAL AND METHODS}

The information was collected through interviews with harpoon fishermen and direct observations during research activities from 1999 to 2014 in Sicilian waters (Mediterranean Sea). Information on some attacks in previous years was also obtained from older fishermen. The interviews were conducted with Sicilian harpoon fishermen, as they have the opportunity to testify and directly observe living swordfish specimens during their fishing activity. Overall 27 fishermen were interviewed, having a mean 
age of $42 \pm 20$ years (age range: $16-70$ years), 12 of which were older than 60 years. All data obtained were analyzed and categorized as true if at least 2 of the interviewed harpoon fishermen reported the same event. When the information was obtained by the story of only one fisherman, it was reported as "historical memory".

\section{RESULTS AND DISCUSSION}

All collected records are summarized in Table 1. The table includes true records, historical memories of swordfish attacks collected during the interviews and direct observations obtained by researchers during sampling activities onboard harpoon vessels.

Graphic representation of the observation of an attack is reported in Fig. 1.

Overall, 29 cases of swordfish aggressive behavior towards boats were documented. If we consider the years between 1999 and 2014 (years in which the research was carried out) a mean value of 1.50 attacks for a year resulted. These attacks did not cause any injuries to fishermen, only damages to the boats were recorded in some cases. Descriptions of the events (Table 1) indicate that swordfish attacked mainly when provoked and in several cases, it tried to pierce its 'enemy' by the bill. However, several fishermen reported that the attack did not culminate with a real damage to the target, since the fish behavior was based on flipping the boat over by swimming aggressively, only simulating attacks, without piercing the boat by the 'sword'. The bill, generally used in feeding strategy, in this case is used for defensive purpose. The swordfish visual capability (FRITCHES et al., 2005) allows this species to choose a specific target during its aggressive behavior. In several reported cases the swordfish, when harpooned, retaliates by attacking its assailant. Moreover, several attacks reported in Table 1 are referred to a fish-pair, sighted during the peak of swordfish reproductive period, in June and July (ROMEO et al., 2015). We can suppose that in these cases the attacks reflect the tendency to perceive the fishing vessel as a probable enemy and/or main reason of the mate death, confirming as reported by SISCI

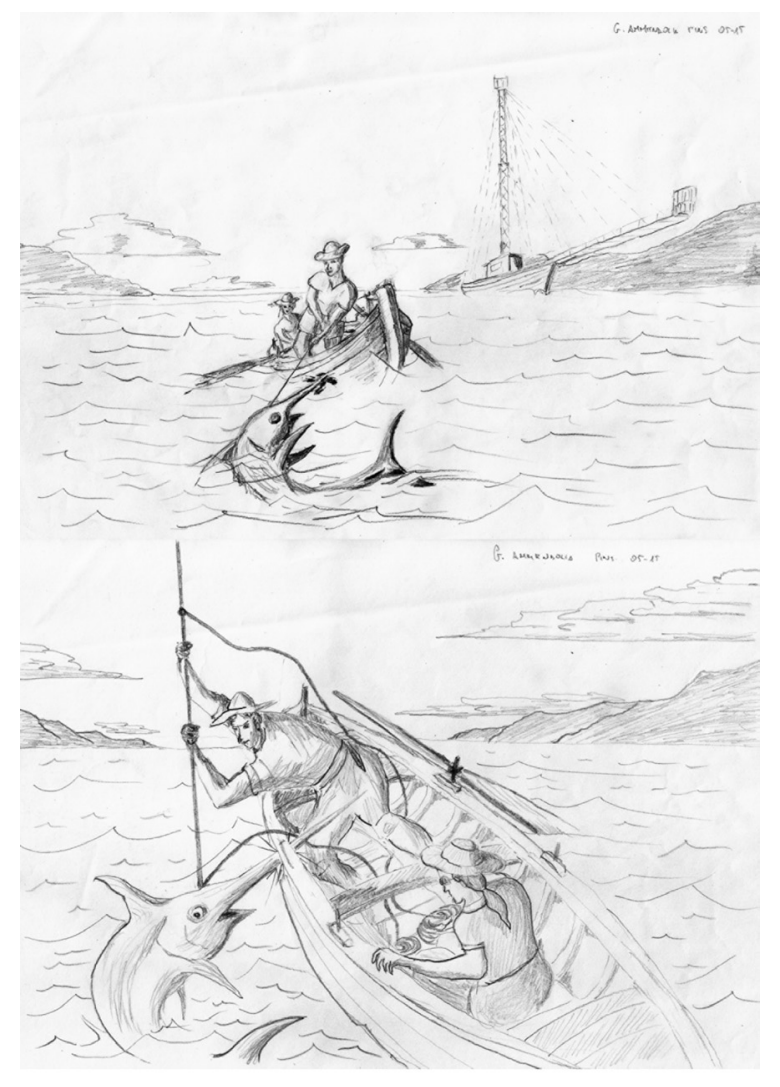

Fig. 1. Illustration (G. Ammendolia) showing a harpooned swordfish attacking a supporting boat of an harpoon fishing vessel operating in the Strait of Messina.

(2005) about male's fidelity to female during the breeding season. The swordfish harpoon fishing (DI NATALE et al., 2005; ROMEO et al., 2015) carried out in Italian waters has the feature of a seasonal activity, being performed between May and August/September, a period that also includes the swordfish breeding season in the study area (ROMEO et al. 2015). It is well known among harpoon fishermen that female and male swordfish are usually swimming together near the surface during the reproductive period in order to spawn (ROMEO et al., 2009b) and that males tend to protect its mate, becoming aggressive. As reported by ROMEO et al. (2015), this behavior represents an opportunity of increasing catches for harpoon fishermen: when a pair is sighted, the fisherman first harpoons the largest specimen (usually the female) keeping it in the water alongside the vessel and waiting for the male to approach. Indeed, male does not leave its mate and tries to defend it, giving the harpooner a greater chance 


\begin{tabular}{|c|c|c|c|c|c|c|c|c|c|c|c|c|}
\hline 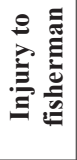 & & ' & ' & & ' & 1 & ' & & & ' & ' & ' \\
\hline 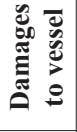 & $\rtimes$ & $x$ & $\rtimes$ & $\rtimes$ & ' & $x$ & ' & ' & I & ' & ' & $x$ \\
\hline 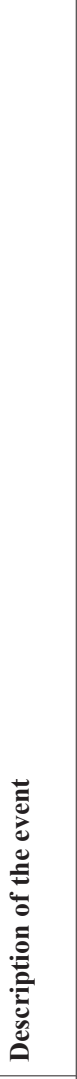 & 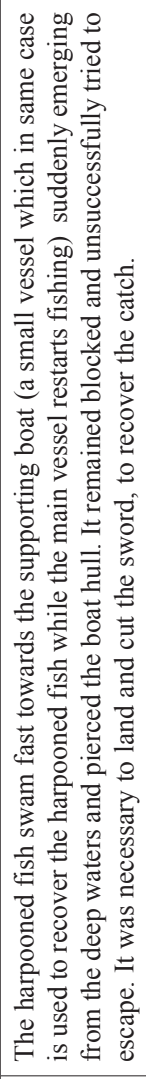 & 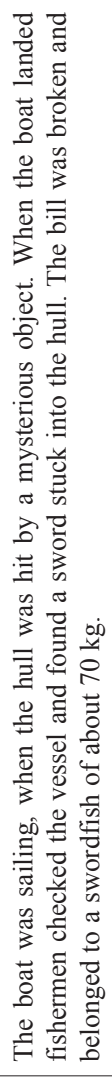 & 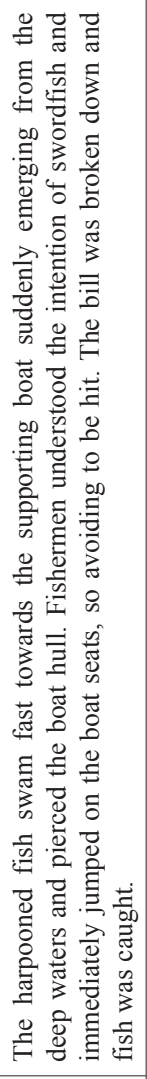 & 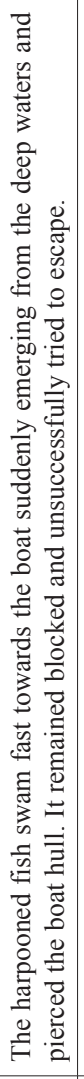 & 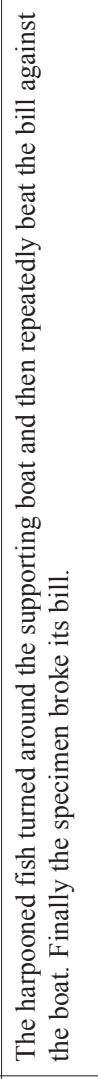 & 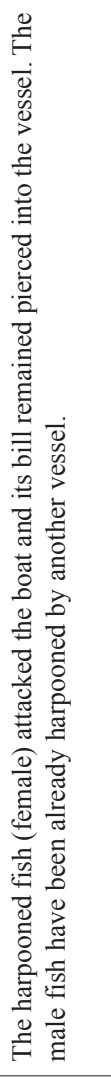 & 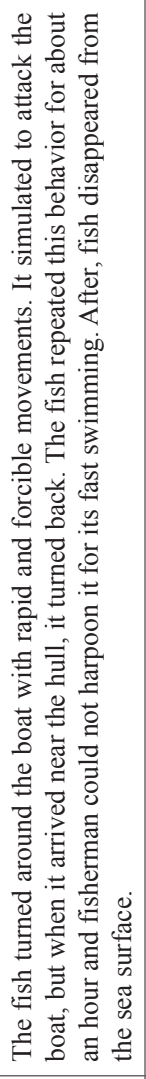 & 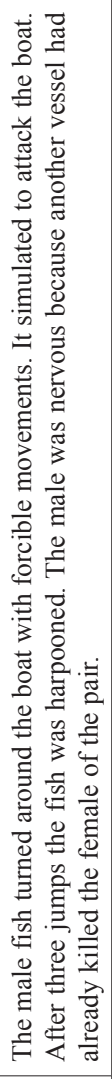 & 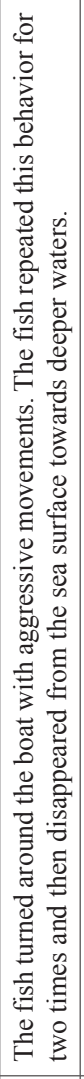 & 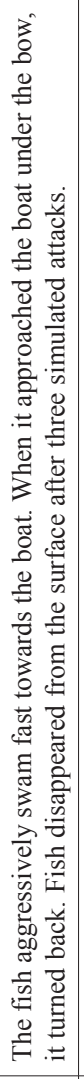 & 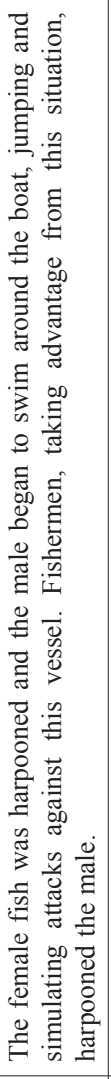 & 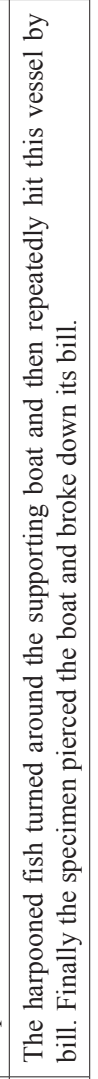 \\
\hline ڤે & ' & ' & I & 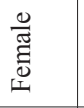 & 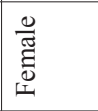 & 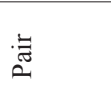 & $\frac{\frac{0}{\pi}}{\frac{\pi}{2}}$ & 䓌 & & ' & 㤩 & $\frac{0}{\tilde{J}}$ \\
\hline 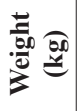 & 8 & $i$ & 6 & $\bar{\sigma}$ & $\stackrel{\cong}{\beth}$ & $\bar{\sigma}$ & rq & $m$ & $\begin{array}{l}8 \\
2\end{array}$ & in & $\approx$ & F \\
\hline & 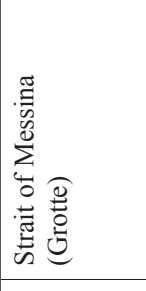 & 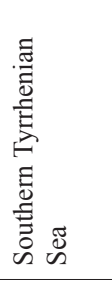 & 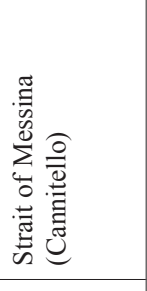 & 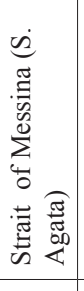 & 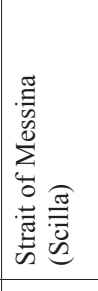 & 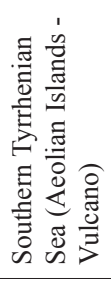 & 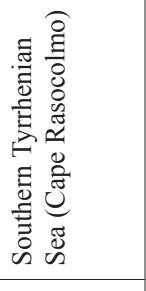 & 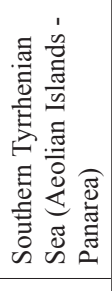 & 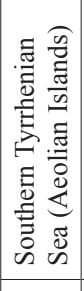 & 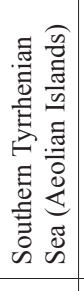 & 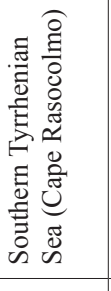 & 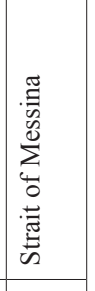 \\
\hline$\overline{\bar{z}}$ & $\Xi$ & $\Xi$ & $=$ & $\overrightarrow{\check{n}}$ & $\Xi$ & 䛼 & $\Xi$ & 吾 & $\Xi$ & $\Xi$ & $\Xi$ & $\Xi$ \\
\hline$\stackrel{\bar{\varpi}}{\beth}$ & 。े & $\hat{\stackrel{n}{\sigma}}$ & $\sigma$ & 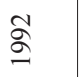 & 茨 & $\stackrel{ }{2}$ & $\stackrel{\sigma}{2}$ & సั & ఫ্ণ & نे & હે̊ & ఫ્ه \\
\hline 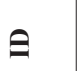 & * * & $\stackrel{*}{*}$ & $m$ & $\vec{\sigma}$ & 粪 & 6 & $\pi$ & $\infty$ & $a$ & $\stackrel{*}{*} \stackrel{\text { * }}{\circ}$ & $=$ & $\simeq$ \\
\hline
\end{tabular}




\begin{tabular}{|c|c|c|c|c|c|c|c|c|c|c|c|c|c|c|c|c|}
\hline ' & ' & & ' & ' & ' & ' & ' & 1 & 1 & & I & 1 & ' & & & ' \\
\hline ' & ' & & ' & $x$ & ' & ' & $x$ & ' & 1 & 1 & ' & ' & I & & & ' \\
\hline 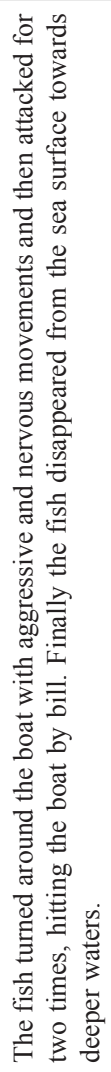 & 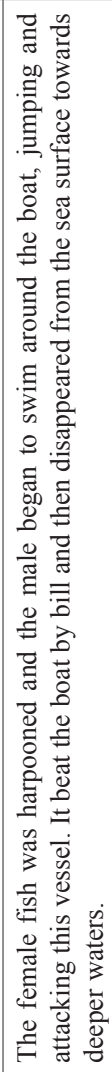 & 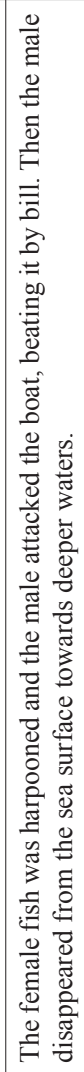 & 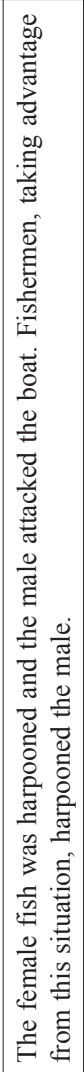 & 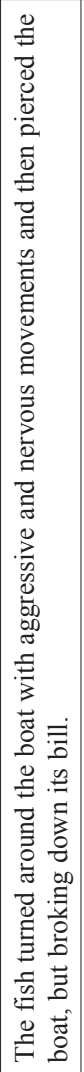 & 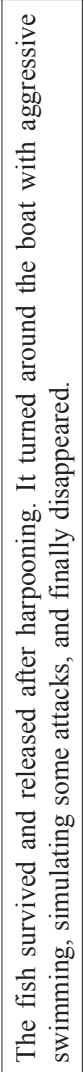 & 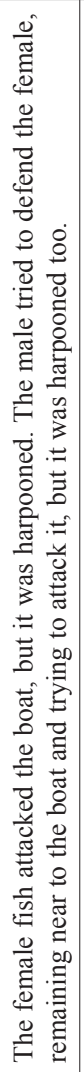 & 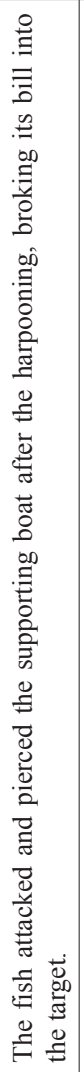 & 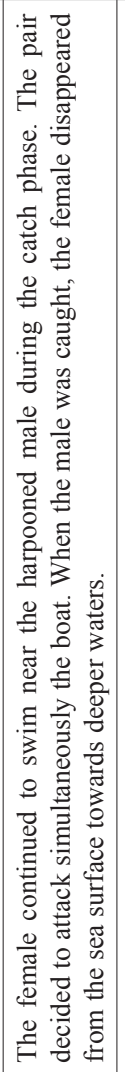 & 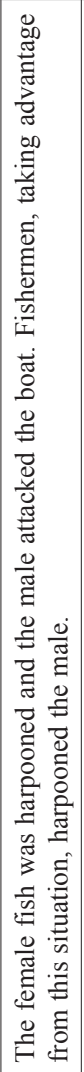 & 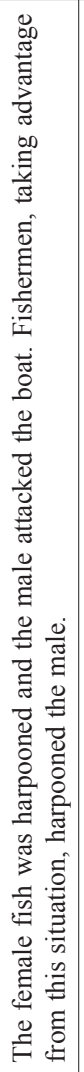 & 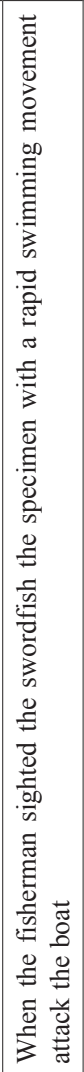 & 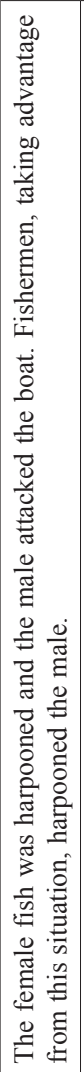 & 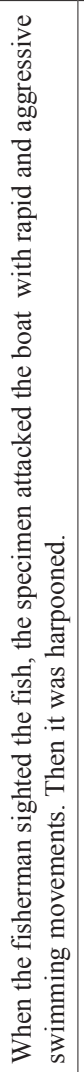 & 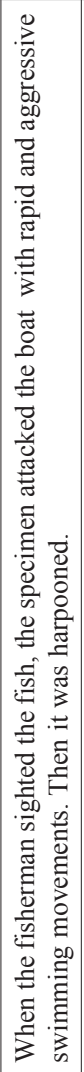 & 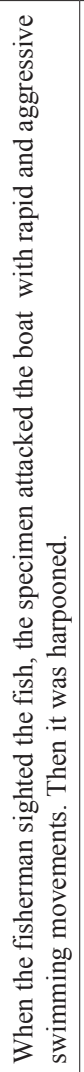 & 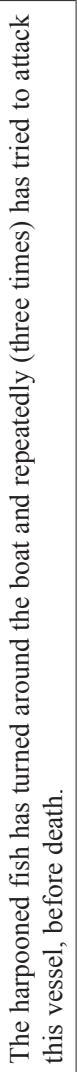 \\
\hline ' & 芯 & 音 & 言 & $\frac{0}{\tilde{I}}$ & $\frac{0}{\tilde{J}}$ & $\exists$ & $\frac{0}{\tilde{J}}$ & 言 & 薦 & 莺 & 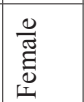 & 离 & $\bar{\Sigma}$ & $\sum$ & $\sum^{\pi}$ & $\frac{\frac{0}{\pi}}{\frac{\pi}{2}}$ \\
\hline$\underset{q}{q}$ & in & & ' & $\infty$ & in & $\pi$ & $\stackrel{\infty}{\sigma}$ & $\frac{\stackrel{\overbrace{}}{2}}{2}$ & $\stackrel{n}{m}$ & లు & q & 年 & $\stackrel{\infty}{\infty}$ & $\hat{m}$ & $\stackrel{m}{m}$ & 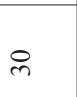 \\
\hline 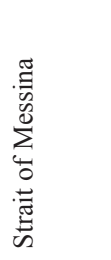 & 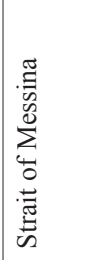 & 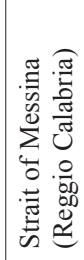 & 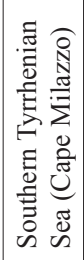 & 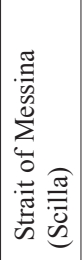 & 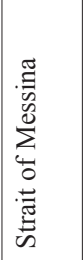 & 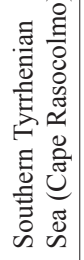 & 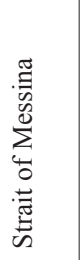 & 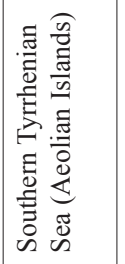 & 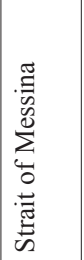 & 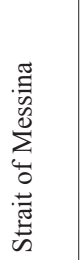 & 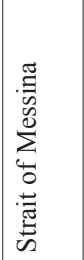 & 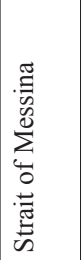 & $\begin{array}{l}\text { 䔍 } \\
\text { 离 }\end{array}$ & 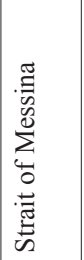 & 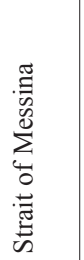 & 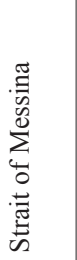 \\
\hline$=$ & $\Xi$ & $\Xi$ & $\Xi$ & 3 & $=$ & $=$ & 3 & $\Xi$ & 3 & 3 & $\Xi$ & $=$ & 3 & 3 & $\Xi$ & $\Xi$ \\
\hline ڤ్రి & 灾 & 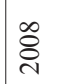 & ठ্ণે & $\stackrel{\circ}{\stackrel{\sim}{\sim}}$ & $\stackrel{\circ}{\stackrel{\sim}{\sim}}$ & సి & $\stackrel{\sim}{\text { ते }}$ & $\stackrel{m}{\stackrel{\sim}{\sim}}$ & సి & $\sqrt{1}$ & $\overrightarrow{\mathrm{N}}$ & $\stackrel{\sim}{\text { ¿ }}$ & $\overrightarrow{\mathrm{N}}$ & 穴 & $\underset{\sim}{\stackrel{\sim}{\sim}}$ & $\stackrel{\vec{N}}{\vec{N}}$ \\
\hline g & \pm & $\begin{array}{l}* \\
\stackrel{*}{*} \\
\stackrel{4}{n}\end{array}$ & $\stackrel{0}{2}$ & $=$ & 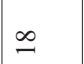 & - & 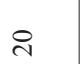 & $\vec{\sim}$ & तี & $\tilde{\lambda}$ & $\stackrel{\ddagger}{\sim}$ & $i$ & N & $\hat{\sim}$ & $\stackrel{\infty}{\sim}$ & ते \\
\hline
\end{tabular}


to catch additional specimens. In reversed situation, females usually do not defend males but escape.

Only the attack occurred in June 1973 remained unexplained. Differently from the others, which regarded harpooned specimens or cases in which a fish defended its mate, in this event, a mysterious object hit the boat hull while sailing, but no fish were noticed on the sea surface. When the boat landed, fishermen found a broken bill stuck into the hull, presumably belonging to a swordfish of about $70 \mathrm{~kg}$. Is it possible that the swordfish had already lost its mate in a harpooning and attacked the boat similar to its first enemy? We cannot prove this hypothesis, but it is probable. Furthermore, what is the destiny of the specimens that escape the catch but break down their bill in an attack? Considering the high importance of the bill for swordfish, playing a significant role in feeding strategy and defense (SCOTT \& TIBBO, 1968; STILLWELL \& KOHLER, 1985; HABEGGER et al., 2015), we can hypothesize that the loss of the bill can lead to premature death.

Several records of swordfish attacks were reported during 2014. Even if the historical memory may be lost during the years, this phenomenon can be partly explained by a recovery of the swordfish resources in the fishing area rather than a change in the fish behavior. Indeed, during the previous years, especially from 1999 to 2005 , few pieces of attacks' evidence may be driven by the decrease of the swordfish resources in the study area related to the high fish pressure mainly due to driftnet fishing in all Mediterranean waters (ICCAT SCRS, 2013). The harpoon catches in the study area during 19992005 decreased too, and only after this period they showed a positive trend (DI NATALE et al., 2005; ROMEO et al., 2015). The implementation of the EC Regulation (n. 849/97, 1239/98 and n. 809/2007; ICCAT Rec. 03-04; GFCM Rec. 2005/3), which imposes limits on the swordfish fishing, probably has been showing its effect on the harpoon fishing activity since 2006, with an increase in both the mean fish size and the number of fish-pairs (ROMEO et al., 2008, 2015).
Several documented records of swordfish attacks to humans, ships, submersibles and fishing boats mainly in ocean waters, were collected and described in a revision chapter by ELLIS (2013). In the Mediterranean Sea, swordfish aggressive behavior against fishing vessels was known from ancient times, as reported in a revision of Oppiano Cilice's epic (LAMPREDI, 1838). Moreover, SPALLANZANI (1776) described the harpoon fishing activity in the Strait of Messina, underlining the risk of swordfish aggressiveness during some harpoon catch procedures. A Sicilian newspaper published information on swordfish attack on a fishing boat, after harpooning (ILLUSTRAZIONE DEL POPOLO 1947). In the southern Tyrrhenian Sea (Milazzo), a swordfish attack to a human was reported in 1952 by a national newspaper (LA DOMENICA DEL CORRIERE, 1957). The published photo showed a swordfish injuring a fisherman's abdomen. The national newspaper "La Domenica del Corriere" illustrated two records of swordfish attacks on 21 September 1952 and 27 October 1957. Both attacks occurred in the Tyrrhenian Sea (Gulf of Milazzo and Gulf of Naples). In the first case, a swordfish injured a fisherman's abdomen, during fishing activity, whereas in the last case a large specimen (larger than $300 \mathrm{~kg}$ ) impaled a fishing boat listing it on a side, lost its broken bill and then escaped. No other published data on swordfish attacks to humans or vessels seem to be collected in the Mediterranean Sea.

Differently from other areas where swordfish wreaked injuries to humans (GALBIS et al., 2002; GOOI et al., 2006; MENDONÇA-CARIDAD et al., 2008; HADDAD et al., 2009; GEORGIADOU et al., 2010), results of the present paper highlighted no direct damages to fishermen. In most cases, studies regarded medical aspects of injuries to humans, without reporting additional information on the context of these accidents, even if in some case fishermen were involved (HADDAD et al., 2009; GALBIS et al., 2002; MENDONÇA-CARIDAD et al., 2008). The testimony of harpoon fishermen highlighted in all attacks a clear choice of target, aggressive use of bill toward the vessel, since the fish seems to recognize the boat as the main cause of disturb and/or mate death (in a case of 
a pair). Although the attacks described in this paper were always caused by a defensive behavior, it is still unclear if the fish actually perceives people or a boat as a threat. The reasons for several attacks to boats or humans, reported in the literature, are still unexplained and swordfish was apparently unprovoked (ELLIS, 2013).

\section{CONCLUSIONS}

The present paper underlines the capacity of the swordfish in defending its mate and generally, it does not represent a serious danger to humans, however, we cannot exclude a potential risk to fishermen targeting swordfish. It is also true that the experience of harpoon fishermen of the study area plays an important role in avoiding any injuries or damages to humans. Fishermen greatly respect their prey and fear its sword. In particular, when fishermen operate on a supporting boat (a small vessel which in some cases is used to recover the harpooned fish while the main vessel continues fishing), they carefully monitor swimming and behavior of the harpooned fish and when they suspect of an attack, they jump on the boat seats avoiding to be hit by the sword pierced into the hull.

An improved understanding of the behavior, distribution and ecological role of the Mediterranean swordfish is important, not only to preserve the stock but also to mitigate potential risk for public safety, as also reported in a recent study on conservation and public safety regarding other large marine predators (FERRETTI et al., 2015).

\section{ACKNOWLEDGEMENTS}

Authors are grateful to all Sicilian harpoon fishermen, in particular to Nino ARENA, Pippo ARENA, Tino BILlè, Giuseppe DONATO, Michele DONATO, Nicola DONATO, Nino DONATO, Antonio MANCUSO, Lillo MANCUSO, Massimo MANCUSO, Salvatore MANCUSO, Francesco PONSÙ, Nicolò RUELLO, which collaborated in collecting information and accurately described their fishing experiences and close swordfish encounters.

\section{REFERENCES}

CANESE, S., F. GARIBALDI, L. ORSI RELINI \& S. GRECO. 2008. Swordfish tagging with pop-up satellite tags in the Mediterranean Sea. Coll. Vol. Sci. Pap. ICCAT., 62(4): 1052-1057.

CANESE, S., F. GARIBALDI, M. GIUSTI, T. ROMEO \& S.GRECO. 2004. First successful attempt of swordfish tagging with popup in the Mediterranean Sea. Biol. Mar. Medit., 11: 153.

CAREY, F.G. \& B.H. ROBINSON. 1981. Daily patterns in the activities of swordfish, Xiphias gladius, observed by acoustic telemetry. Fish. Bul., 79: 277-292.

DI NATALE, A., A. CELONA \& A. MANGANO. 2005. A series of catch records by the harpoon fishery in the Strait of Messina from 1976 to 2003. Coll. Vol. Sci. Pap. ICCAT., 58(4): 1348-1359.

DOMENICI, P., A.D.M. WILSON, R.H.J.M. KURVERS, S. MARRAS, J.E. HERBERT-READ, S.STEFFENSEN, S. KRAUSE, P.E. VIBLANC, P. COUILLAUD \& J.
KRAUSE. 2014. How sailfish use their bills to capture schooling prey. Proc. R. Soc. B., pp. 281, DOI: 10.1098/rspb.2014.0444.

ELLIS, R. 2013. Armed and Dangerous. In Swordfish: A biography of the ocean gladiator. University of Chicago Press, (4): 61-90.

FERRETTI, F., S. JORGENSEN, T.K. CHAPPLE, G. DE LEO \& F. MICHELI. 2015. Reconciling predator conservation with public safety. Front. Ecol. Env., 13(8):412-417, DOI: 10.1890/150109. FIERSTINE, H.L. 1997. An Atlantic Blue Marlin, Makaira nigricans, impaled by two species of billfishes (Teleostei: Istiophoridae). Bul. Mar. Sci., 61: 495-499.

FIERSTINE, H.L., G.M. CAILLIET \& J.A. NEER. 1997. Shortfin Mako, Isurus oxyrinchus, impaled by blue marlin, Makaira nigricans (Teleostei: Istiophoridae). Bull. S. Cal. Ac. Sci., 96(3): 117-121.

FRITCHES, K.A., R.W. BRILL \& E.J. WARRANT. 
2005. Warm eyes provide superior vision in swordfishes. Cur. Biol., 15: 55-58.

GALBIS, C., M. MAFE, G. BASCHWITZ \& P. RODRIGUEZ. 2002. Swordfish attack: an unusual cause of penetrating thoracic wound. E. J. Card. Sur., 21, p. 926.

GEORGIADOU, D., G.N. ZOGRAFOS, D. VAIDAKIS, S. AVLONITIS, A. KATOPODI, E.N. TZIRAKIS, P. SIOUTOS, C. DROSSOS, P. LAMPROPOULOU \& G. PAPASTRATIS. 2010. Swordfish bill injury involving abdomen and vertebral column: case report and review. BMC Sur., 10(1):30. DOI:10.1186/1471-2482-10-30.,

GOODE, G.B. 1882. Materials for a History of the Swordfish. Trans. Am. Fish. Soc., 11(1): 84-150.

GOOI, B.H., W. KHAMIZAR \& M.N. SUHAMI. 2006. Swordfish attack - Death by Penetrating Head Injury. Case Report. A. J. Sur., 30 (2): 158-159.

GUDGER, E.W. 1938. Tales of attacks by the ocean gladiator-How the swordfish, Xiphias gladius, wreaks occasional vengeance by spearing the dories of the fishermen who persecute him. Proc. U. S. Nat. Hist., 41:128-137.

GUDGER, E.W. 1940. The Alleged Pugnacity of the Swordfish and the Spearfishes as Shown by Their Attacks on Vessels:(A Study of Their Behavior and the Structures which Make Possible These Attacks). Royal Asiatic Society of Bengal, 12(2):315.

HABEGGER, M.L., M.N. DEAN, J.W. DUNLOP, G. MULLINS, M. STOKES, D.R. HUBER, D. WINTERS \& P.J. MOTTA. 2015. Feeding in billfishes: inferring the role of the rostrum from a biomechanical standpoint. J. Exp. Biol., 218(6): 824-836.

HADDAD, V. \& J.L. DE FIGUEIREDO. 2009. Attack Upon a Bather by a Swordfish: A Case Report. Wild. Env. Med., 20(4): 344-346.

ILLUSTRAZIONE DEL POPOLO. 1947. Supplemento della nuova gazzetta del popolo, 20 April 1947. Anno 27, n. 16.

LA DOMENICA DEL CORRIERE 1957. Supplemento illustrato del nuovo corriere della sera, 27 October 1957. Anno 59, n. 43.

LAMPREDI, U. 1835. La Cinegenetica,e l'Alieutica o sia la Caccia, e la Pesca. Poemi di Oppiano
Cilice metricamente volgarizzati: 165-167.

LEE, H.J., Y.J. YONG, L.M. CHANG \& W.L. WU. 2009.

Propulsion strategy analysis of high-speed swordfish. Trans. Jap. Soc. Aer. Spac. Sci., 52 (175): 11-20.

MENDONÇA-CARIDAD, J.J, P. JUIZ, L. FRANCOS \& M. RODRIGUEZ. 2008. Swordfish bill injury involving the pterygomaxillary fossae: surgical management and case report. J. Oral Maxil. Surg., 66 (8):1739-43.

OVCHINNIKOV, V.V. 1970. Swordfish and billfishes in the Atlantic Ocean. Ecol. Func. Morphol. NOAA NMFS TT 71-50011. 76 pp.

ROMEO, T., F. FERRETTI, P. CONSOLI, S. CANESE \& F. ANDALORO. 2008. Assessment of the Mediterranean swordfish based on Italian harpoon fisheries data. In: ICES Annual Conferences (ASC), Halifax, Nova Scotia, Canada 22-26 September 2008, K:16.

ROMEO, T., P. CONSOLI, L. CASTRIOTA \& F. ANDALORO. 2009a. An evaluation of resource partitioning between two billfish, Tetrapturus belone and Xiphias gladius, in the central Mediterranean Sea. J. Mar. Biol. Ass. UK., 89 (4): 849-857.

ROMEO, T., P. CONSOLI, S. GRECO, S. CANESE \& F. ANDALORO. 2009b. Swordfish (Xiphias gladius, Teleostea: Xiphiidae) surface behaviour during reproductive period in the central Mediterranean Sea (southern Tyrrhenian Sea). Mar. Bio. Div. Rec., 2: e45 ROMEO, T., P. CONSOLI, A. PUNZON, L. MODICA, F. RAFFA, P. PERZIA, P. BATTAGLIA, V. ESPOSITO, \& F. ANDALORO. 2010. Swordfish (Xiphias gladius Linnaeus 1758) harpoon fishery: a method of evaluation of the swordfish presence in the Strait of Messina (Central Mediterranean Sea). J. Appl. Ichthyol., 26: 886-891.

ROMEO, T., P. BATTAGLIA, C. PEDÀ, P. PERZIA, P. CONSOLI, V. ESPOSITO \& F. ANDALORO. 2011a. Pelagic cephalopods of the central Mediterranean Sea determined by the analysis of the stomach content of large fish predators. Helgol. Mar. Res., 66 (3): 295-306.

ROMEO, T., P. PERZIA, V. ESPOSITO, D. MALARA, P. BATTAGLIA, P. CONSOLI, S. CANESE \& F. ANDALORO. 2011b. Relationship between 
swordfish swimming behaviour and sea surface temperature in the central Mediterranean Sea during the reproductive period. Mar. Biol. Res., 7: 186-194.

ROMEO, T., P. BATTAGLIA, S. RAICEVICH, P. PERZIA \& F. ANDALORO. 2015. Swordfish harpoon fishery in the Mediterranean Sea: recent data to implement the Marine Strategy Framework Directive and the EcAp (Ecosystem Approach) process. Fish. Res., 161:191-199.

SAGONG, W., W.P. JEON \& H. CHOI. 2013. Hydrodynamic characteristics of the sailfish (Istiophorus platypterus) and swordfish (Xiphias gladius) in gliding postures at their cruise speeds. PLoS ONE 8: e81323.

SCOTT, W.B. \& S.N. TIBBO. 1968. Food and feeding habits of swordfish, Xiphias gladius, in the Western North Atlantic. J. Fish. Res. B..Can., 25(5): 903-919.

SHIMOSE, T., K. YOKAWA, H. SAITO \& K. TACHIHARA. 2007. Evidence for use of the bill by blue marlin, Makaira nigricans, during feeding. Ichthyol. Res., 54(4): 420-422.
SISCI, R. 2005. La caccia al pescespada nello Stretto di Messina. Messina, Sfameni. pp. 223

SPALlANZANI, L. 1776. Pescagione dei pesci spada nel medesimo Stretto (di Messina). In Viaggi alle due Sicilie e in alcune parti dell'Appennino. Tomo III. Milano. Dalla Società tipografica de' classici italiani 30 : 90-92.

STILLWELL, C.E \& N.E. KOHLER. 1985. Food and feeding ecology of the swordfish (Xiphias gladius) in the western North Atlantic Ocean with estimates of daily ration. Mar. Ecol. Progr. Ser., 22:239-247.

TAKAHASHI, M., H. OKAMURA, K. YOKAWA \& M. OKAZAKI. 2003. Swimming behavior and migration of a swordfish recorded by an archival tag. Mar. Fresh. Res., 54(4): 527534.

WISNER, R. 1958. Is the spear of istiophorid fishes used in feeding? Pac. Sci., 12: 60-70.

ZARUDSKI, E.F.K \& R.L.HAEDRICH. 1974. Swordfish (Xiphias gladius) attacks submarine (Alvin). Oceanol., 3:111-116.

Received:17 January 2016

Accepted: 20 January 2017 


\title{
Nedavni zapisi napada igluna na ribarske brodice u vodama oko Sicilije (Sredozemno more)
}

\author{
Teresa ROMEO, Giovanni AMMENDOLIA, Simonepietro CANESE, \\ Franco ANDALORO i Pietro BATTAGLIA
}

Kontakt e-adresa: teresa.romeo@isprambiente.it

\begin{abstract}
SAŽETAK
Razmatrani su nedavni napadi igluna na ribarske brodice iz sicilijanske flote te je opisan poseban obrazac ponašanja koji su ove ribe imale kada su se približavale ribarima.

Informacije su prikupljane u razdoblju između 1999. i 2014. u vodama oko Sicilije (Sredozemno more) kroz razgovore s ribarima koji love harpunima i kroz izravna promatranja tijekom istraživanja. Također smo izvijestili i o drugim slučajevima napada koji su se dogodili prijašnjih godina. Sveukupno je zabilježeno 29 slučajeva agresivnog ponašanja igluna naspram ribarskih plovila. Igluni su uglavnom napadali kada bi ih se izazvalo ili kad bi htjeli obraniti svog para, te su, u nekoliko slučajeva pokušali probosti brod sabljom. Neki su napadi završili materijalnom štetom na meti dok ozljeđivanja ljudi nisu zabilježena.
\end{abstract}

Ključne riječi: Xiphias gladius, ponašanje, napad, rizik za ljude, lov harpunima, Sredozemno more 